University of Nebraska - Lincoln

DigitalCommons@University of Nebraska - Lincoln

Faculty Publications from the Harold W. Manter Laboratory of Parasitology

2003

Cystic Echinococcosis in the Arctic and Sub-Arctic

Robert L. Rausch

University of Washington, rausch@u.washington.edu

Follow this and additional works at: https://digitalcommons.unl.edu/parasitologyfacpubs

Part of the Parasitology Commons

Rausch, Robert L., "Cystic Echinococcosis in the Arctic and Sub-Arctic" (2003). Faculty Publications from the Harold W. Manter Laboratory of Parasitology. 515.

https://digitalcommons.unl.edu/parasitologyfacpubs/515

This Article is brought to you for free and open access by the Parasitology, Harold W. Manter Laboratory of at DigitalCommons@University of Nebraska - Lincoln. It has been accepted for inclusion in Faculty Publications from the Harold W. Manter Laboratory of Parasitology by an authorized administrator of DigitalCommons@University of Nebraska - Lincoln. 


\title{
Cystic echinococcosis in the Arctic and Sub-Arctic
}

\author{
R. L. RAUSCH \\ Department of Comparative Medicine, University of Washington, School of Medicine, Seattle, WA 98195-7190, USA
}

SUMMARY

The northern biotype of Echinococcus gramulosus occurs throughout the holaretic zones of tundra and taiga, from eastern Fennoscandia to the Bering Strait in Eurasia and in North America from arctic Alaska approximately to the northern border of the United States. The cycle of the cestode is complex in taiga at lower latitudes, because of the greater diversity of potential hosts. In the Arctic and Subarctic, however, four patterns of predator/prey relationships may be discerned. Two natural cycles involve the wolf and wild reindeer and the wolf and elk (moose), respectively. Where decr of the two species coexist, both are prey of the wolf; the interactions of the wolf and elk are here described on the basis of long-term observations made on Isle Royale (in Lake Superior near the southern limit of taiga), where only the wolf and elk serve as hosts for E. granulosus. A synanthropic cycle involving herding-dogs and domesticated reindeer caused hyperendemicity of cystic echinococosis in arctic Eurasia, mainly in northeastern Siberia. The 4th pattern, a semi-synanthropic cycle, formerly existed in Alaska, wherein sled-dogs of the indigenous hunters became infected by consuming the lungs of wild reindeer. The sequence of changes in life-style inherent in the process of acculturation affected the occurrenec of cystic echinococcosis among nomadic Iñupiat in arctic Alaska. When those people became sedentary, the environs of their early villages soon became severely contaminated by faeces of dogs, and cases of cystic echinococcosis occurred. Compared to cystic echinococcosis caused by $E$. gramulosus adapted to synanthropic hosts (dog and domestic ungulates), the infection produced by the northern biotype is relatively benign. Nearly all diagnosed cases of cystic echinococosis $(>300)$ in Alaska have occurred in indigenous people; only one fatality has been recorded (in a non-indigenous person). After sled-dogs were replaced by machines, cases have become rare in Alaska. A similar effect has been observed in Fennoscandia, in the Saami and domesticated reindeer. Recent records indicate that the prevalence of cystic echinococcosis is increasing in Russia, suggesting that dogs are used there in hording.

Key words: Echinococcus granulosus, cycles, wolf, domestic dog, Rangifer tarandus, domesticated rcindcer, Alces alces, cystic echinococcosis.

\section{INTRODUCTION}

The variant of Echinococcus granulosus (Batsch, 1786) that I have designated the northern biotype occurs in its natural hosts throughout the holarctic zones of tundra and taiga. 'That it differs biologically from strains adapted to domestic ungulates was recognized by Cameron (1960), who proposed for it the designation Echinococcus granulosus var. canadensis. Its rank was elevated to that of subspecies, E. granulosus canadensis, by Webster \& Cameron (1961). During recent years, cestodes morphologically identifiable as E. gramulosus have been shown to differ genetically, manifested in metacestodes by some degree of adaptation to the respective species of domestic ungulates. Such host-adapted variants usually have been designated 'strains,' but their taxonomic status remains to be established (Thompson \& McManus, 2002).

'The natural final host of the northern biotype in the Arctic and Subarctic is the wolf, Canis lupus L. Its derivative, the domestic dog, C. lupus forma familiaris, serves equally well as host of the strobilar stage. The intermediate hosts in those regions are the wild reindeer, Rangifer tarandus (L.), and the elk, Alces alces (L.) (designated 'moose' in North America). The metacestode is found commonly in domesticated reindeer. Echinococcus granulosus evidently does not occur in Greenland (Smith, 1957, p. 31); information about other arctic islands is scanty, and not considered here.

Cystic echinococcosis caused by the northern biotype occurs typically in indigenous peoples engaged in the hunting of wild cervids or in reindeerherding with use of dogs. In the human host, the metacestode exhibits distinctive characteristics. The laminated membrane is often thin and poorly developed; protoscoleces may be few or lacking; the loci of the metacestodes are almost invariably the lungs and liver, with the greater proportion in the former organs; immunogenesis is slight or lacking, precluding effective use of immunodiagnostic tests; recurrence of infection following surgery is evidently unknown and complications are rare. The course of infection in indigenous persons is typically benign, and self-cure, following rupture and expulsion of pulmonary cysts and fluid, is not uncommon (Meltzer et al. 1956; Wilson, Diddams \& Rausch, 1968; Huldt, Johansson \& Lanto, 1973; and others). 'To my knowledge, only a single fatal case of cystic echinococcosis has been recorded among more than 300 cases in Alaska and a comparably large number in Canada (Castrodale et al. 2002). Molecular-genctic analysis confirmed that the northern biotype was the etiologic agent in the fatal case (McManus et al. 2002). That the patient was Caucasian is of interest, 
since apparently only one additional case in a person of that ethnic group has been recorded in Alaska. One is tempted to consider that the low degree of pathogenicity among indigenous peoples in the Arctic and Subarctic may be indicative of some adaptation to the metacestode, acquired over many millennia by hunters and, in Eurasia, herders of reindeer (see also Huldt et al. 1973).

Four patterns are discerned here in the cycle of the northern biotype in the zones of tundra and taiga. Two natural cycles involve the wolf and 2 species of deer, the reindeer and the elk (moose), respectively. A synanthropic cycle is maintained when domesticated reindeer are herded with dogs. A semisynanthropic cycle results when sled-dogs used by hunters for transportation have access to the viscera of wild deer infected through coexistence with wolves.

CYCLES

On the tundra, wild reindeer are the major intermediate host of E. granulosus, as well as of 2 holarctic species of the genus Taenia. Within the taiga, where they overwinter, the reindecr share habitat with elk. At lower latitudes, cervids and canids of additional species are involved in the cycles; they are not considered in this review.

\section{Wolf-wild reindeer}

Wolves occur throughout both zones, but their numbers vary seasonally on tundra (Fig. 1). Under constraints of social rank, they breed from late February to April and the young are born after a gestation period of ca. 63 days (Mech, 1970, Table 12). In spring, females, when pregnant, usually remain in the vicinity of their dens for about 3 weeks prior to parturition. They lactate for about 1.5 months. At an age of about a month, the young begin to consume regurgitated flesh that is cxpelled at the den by the adults (Pavlov, 1990). Beginning at about that time, infection of the pups by $E$. granulosus becomes possible. One case of such early infection involved a pup captured in Alaska when about 3 months old; it expelled (in rather fluid faeces) many fully developed strobilae during the first days in captivity (R. L. Rausch, unpublished). As the young wolves develop, they and their female parent consume prey brought to the den by members of the pack (Murie, 1944). When the pups are old enough to leave the den, they are taken to frequently changed rendezvous-sites, where they are left while the adults hunt (Mech, 1970; and others). In autumn or early winter, the young animals join the pack and participate in hunting (Kozlov, 1966; Mech, 1970). Wolves that establish their dens near calvinggrounds prey extensively on the newborn deer. The calves, however, soon are able to run as rapidly as the adult reindeer (Kelsall, 1968). Thereupon, the wolves prey on reindeer as available or consume other animals.

In Alaska, the western arctic herd of wild reindeer numbered about 430000 in 1999 , when the last census was made (M. Robus, personal communication). In the Soviet Union, wild herds by about 1960 had been much reduced in numbers because of overhunting and competition with domesticated reindeer. According to Geptner, Nasimovich \& Bannikov (1961), the largest herds remained in the Taimyr, in the region of the Lena Delta, and on the Iana-Indigirka tundra, in northeastern Siberia, with a total of 250000-300000 animals. Elsewhere in the Soviet Arctic, numbers did not exceed 100000. More recently, Syroechkovskii (1975, 'Table 1) stated that data from the Glavokhoty RSFSR indicated a total of 608300 in the Soviet Union, as compared with about 200000 in 1961. In Canada, Kelsall (1968) considered that a total of about 668000 wild reindeer was relatively accurate, based on a census made in 1949; the census of 1955 gave an estimate of about 278000 . In Fennoscandia, wild reindeer exist in eastern Finland (HirveläKoski et al. 2003).

In the Brooks Range in arctic Alaska, herds of wild reindeer consisting mainly of pregnant females begin in April to migrate northward from winter range to the calving-grounds on the arctic slope. In a series of 79 deer examined in the central Brooks Range in April 1963, 13 males and one female were up to 3 years in age, while 65 were older females. Metacestodes of $E$. gramulosus were present in the lungs of $2(3 \%)$ of the latter. In northeastern Siberia, where numbers of wild deer had been much reduced, small groups wintered farther north than had been formerly typical (Geptner et al. 1961). No data were available concerning the prevalence of the metacestode in such animals.

In the Brooks Range, adult bulls and younger animals pass northward through the mountains in May and early June. In contrast with much larger herds that often are involved in migration to the winter range, numerous groups of smaller size are present in spring (Fig. 2). Then, by selecting a favourable site for observation, one could easily assess the physical condition of individual animals. The most commonly observed abnormality was bursitis or arthritis involving leg-joints, caused by Brucella suis biovar 4 (designated $B$. rangiferi in Russia) (Rausch \& Huntley, 1978; Zabrodin \& Laishev, 1980). On 8 June 1966, at Chandler Lake, I observed severe bursitis of one or more joints in one deer of each of 6 passing herds, which ranged in numbers from 9 to 65 animals (mean 30). Thus, the rate for a total of 182 deer was $3 \%$. No data for wild herds in Siberia were found, but the prevalence of bursitis in domesticated deer was stated to be $1 \cdot 5-4 \%$ ( $\mathrm{Zabrodin} \&$ Laishev, 1980). Since the older deer are those most 


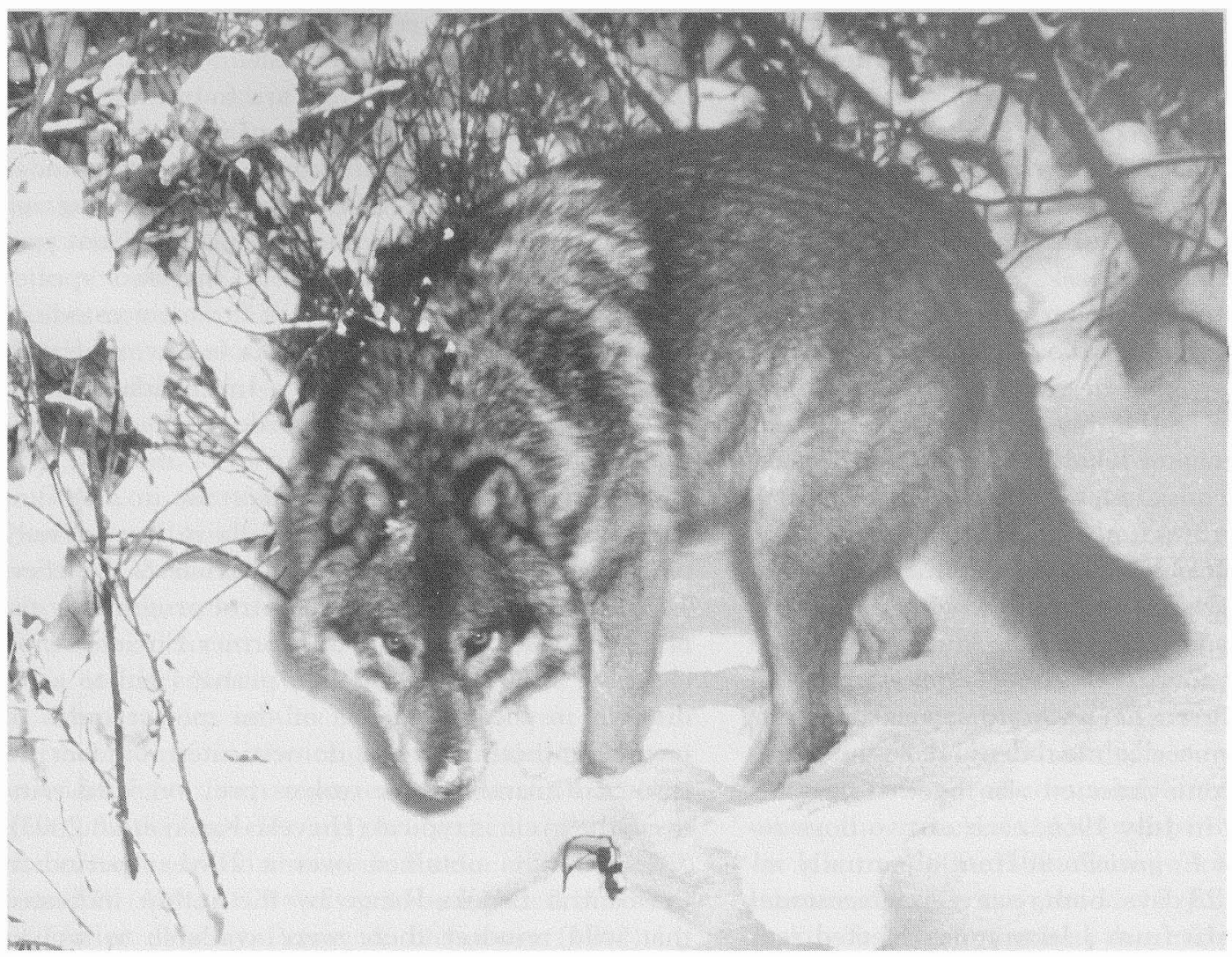

Fig. 1. Wolf, Canis lupus, from south-central Alaska.

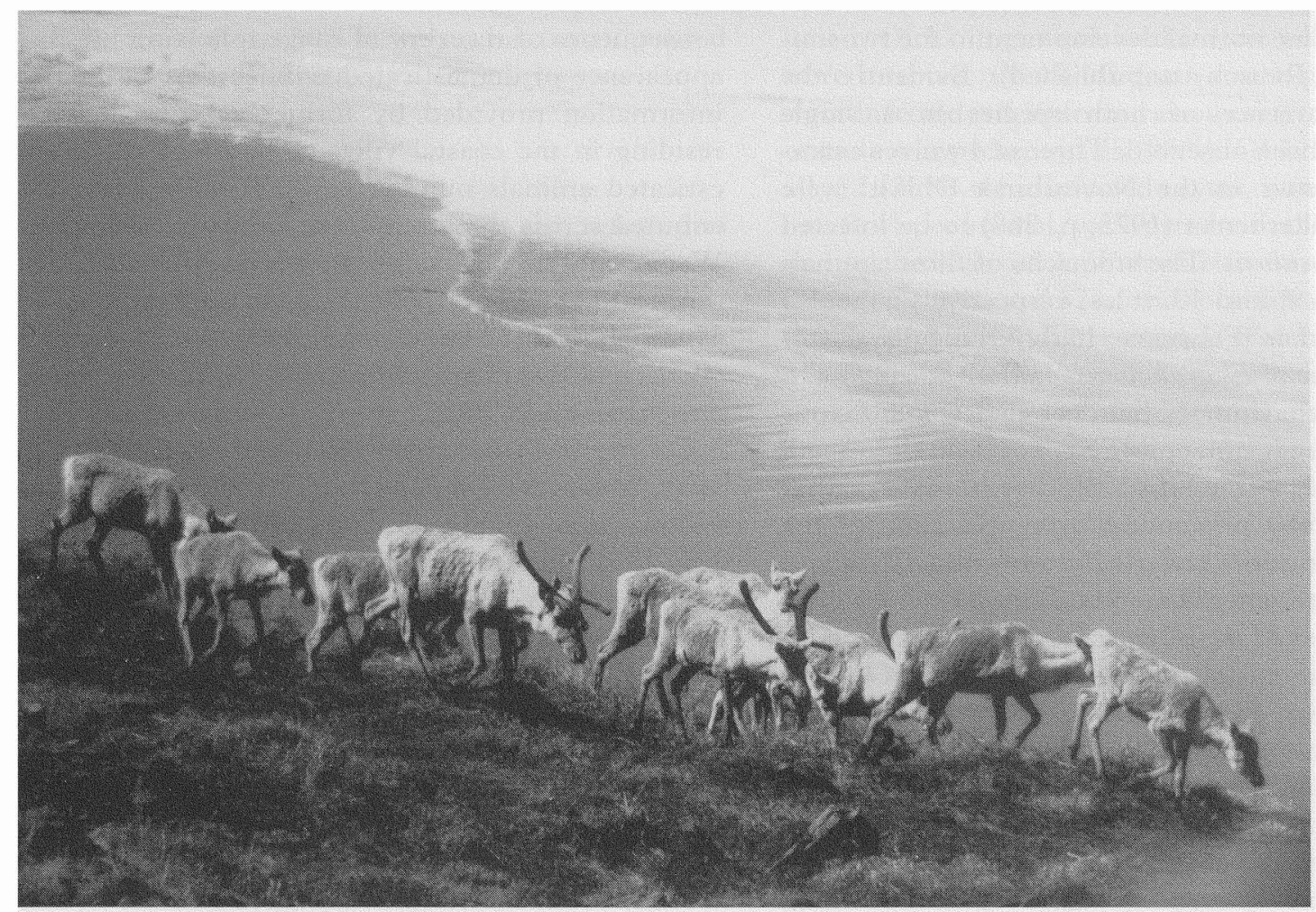

Fig. 2. Wild reindeer, mature males and younger animals, migrating northward along the eastern shore of Chandler Lake, in the central Brooks Range, late May.

likely to have disorders that hamper locomotion, they are most vulnerable to predation by wolves. They also have a higher rate of infection by the metacestode of E. gramulosus. No data were obtained on its prevalence in older animals of mixed herds migrating northward in spring. During 
October 1962, 63 deer traveling toward the winter range (southward) were examined. Of those, 24 were 3 years or less in age, and 39 were older. Two small cysts were present in the lungs of a 2 year-old male, and single cysts were found in the lungs of a 6-7-year-old male and a 9-10-year-old male, for an over-all rate of $5 \%$, and $8 \%$ for older animals.

After wild reindeer disperse on summer range, they may be less vulnerable to predation. On the Eurasian tundra, reindeer appear to make up but a small proportion of the diet of wolves in summer. In different regions of Iakutia, their diet during the warm months consisted of $67-98 \%$ hares, Lepus timidus L. (Tavrovskii et al. 1971). Geptner et al. (1967) stated that not only are small mammals consumed in summer, but that moulting waterfowl are an important resource during the latter part of that season.

On tundra where E. multilocularis is endemic, wolves feeding on arvicoline rodents (voles and $1 \mathrm{~cm}$ mings) may become infected also by that cestode. Experimentally, in July 1966, each of two dogs received 2 cysts of $E$. granulosus from a naturally infected elk. After 23 days, both received metacestodes of E. multilocularis from a laboratory-infected redbacked vole, Clethrionomys rutilus (Pallas). When the dogs were necropsied 38 days after the second exposure, strobilae of both species were found to have undergone normal development in the two animals (R. L. Rausch, unpublished). Evidently the natural occurrence of both species in a single wolf has not been observed. Three of 4 wolves examined in summer in the Novosibirsk Oblast' were found by Lukashenko (1975, p. 268) to be infected by $E$. multilocularis. The stomachs of those animals contained 7, 9, and 13 voles, respectively; the 4th animal, killed in February, harboured fully developed strobilae of $E$. gramulosus.

Specific behaviour of reindeer that would favour ingestion of eggs of taeniids has not been discerned. When grazing on tundra, the herds move rather rapidly, thereby preventing over-utilization of the range, but reindeer reportedly are attracted to and consume materials of animal origin. The Iñupiat of northern Alaska formerly used urine as an attractant on snow-covered pit-traps for reindeer. Geptner et al. (1961, p. 335) stated that '... a deficiency of proteins and mineral matter in their diet ... often compels reindeer to eat animal and other [unusual] food sources ...' In northern Eurasia, the deer have been observed to consume small mammals, such as lemmings and voles, nestlings of ground-nesting birds, shed antlers of deer and bones. 'The consumption of similar items by domesticated reindcer has been reported also by Herre (1955). Kelsall (1968) was of the opinion that consumption of such items is more typical of domestic reindeer on range that is in poor condition, or of animals too closely herded. That wild reindeer are attracted also to faeces of carnivores is conceivable.

In wild reindeer, the cysts are found almost exclusively in the lungs; those found rarely in the liver are usually anomalous and sterile. The metacestodes apparently do not accumulate with increasing age of the host, as is typical in elk (sec below), but perhaps behavioural differences in the two species are involved. The prevalence of the metacestode in wild reindeer in northern Alaska is low, and such appears to be the case generally. In Canada, Harper, Ruttan \& Benson (1955) recorded one of 14 animals in northern Saskatchewan to be infected, and Banfield (1961) found the metacestode in 2 (4\%) of 54 deer. On the Taimyr Peninsula in Russia, only one of 207 was infected (Mitskevich \& Savel'ev, 1975). The drastic predator control programme directed toward wolves in the former Soviet Union (Kozlov, 1966; Pavlov, 1990) perhaps led to a reduction in the prevalence of the metacestodes of taeniids in both wild and domesticated reindeer. In eastern Finland, where wolves prey on wild reindeer, the cycle is typical (Hirvelä-Koski et al. 2003).

Information obtained over a 21 -year period in the central Brooks Range by the author indicated that wild reindeer there were available to wolves throughout the year. By the mid-20th century, wild deer had become widely present on the arctic slope, often to the shores of the Arctic Occan, perhaps as a consequence of recovery of range following the disappearance of domesticated reindecr. According to information provided by former reindeer-herders residing in the coastal villages, herds of the domesticated animals numbering 4000-6000 were distributed across the arctic slope from the vicinity of Wainwright, in the west, to Barter Island, in the east, during 1930-1940. Herders' camps were established as much as $112 \mathrm{~km}$ inland from Point Barrow (Rausch, 1953). Even before that decade, the range was in poor condition.

During the period May-September in 1950 and 1951, wolves were obtained by the Nunamiut in the central Brooks Range during each month excepting July 1951. In the warm months, movements of the deer on the arctic slope and within the mountains are rather complex, and may differ from year to year (Rausch, 1951). Migration of herds through the mountains toward the wintering grounds may begin in August and September, but in 1951 herds of large size were moving southward in November, and some animals still in December. Wolves were widely present. During the period May-September 1951 , the Nunamiut shot or trapped 21 wolves, and considerably more in autumn and winter. In the mountains, at least, the cycle of $E$. granulosus must have been completed throughout the year.

In the taiga in winter, wild reindeer feed on protruding vegetation when snow-cover is light; when snow is deep, they use the forefeet to expose 
vegetation at soil-level (Kelsall, 1968). Whether deer feeding on subnivean lichens and other vegetation have a reduced risk of ingesting eggs of $E$. granulosus is not known. When snow is deep, hunting by wolves is facilitated by their use of the extensive trails made by the reindeer (Kelsall, 1968). Faeces of wolves are deposited in all areas where the deer are present.

In the Arctic, the prevalence of the cestode in wolves is usually high. Of 200 of those canids necropsied in Alaska, 162 originated in the Brooks Range, while the remainder was obtained in taiga. The over-all rate of infection by $E$. gramulosus was $30 \%$ (Rausch \& Williamson, 1959). The greater number of the animals had been killed by the Nunamiut during the interval October-April. In northern Canada, Choquette et al. (1973) recorded rates of infection in wolves as follows: $19(22 \%)$ of 89 in boreal forest in the Yukon; $5(24 \%)$ of 21 in taiga in the Northwest Territories; but none of 61 from tundra in the latter region was infected. Farther south in the taiga of Canada, high prevalences have been reported in wolves, but there deer of other species are involved in the cycle of the cestode. In northeastern Russia, Kikot' (1980) found $10(42 \%)$ of 24 wolves to be infected. A review of earlier data by Petrov \& Delianova (1962) indicated that $E$. gramulosus occurred widely in wolves in the Soviet Union, but records from the Arctic and Subarctic were not included. In eastern Finland, a prevalence of about $30 \%$ in wolves has been reported (Hirvelä-Koski et al. 2003).

\section{Wolf-elk (moose)}

In North America, elk (Alces alces), also referred to as moose in North America and elk in Europe, inhabits the taiga of Alaska and Canada south to ca. latitude $45^{\circ} \mathrm{N}$, with an extension of its range southward in the Rocky Mountains into the United States. In Eurasia, it occurs from Fennoscandia eastward to Chukotka in the north, and southward to about latitude $50^{\circ}$ (Geptner et al. 1961). Geptner et al. stated that the numbers of moose/elk in the Soviet Union had attained a density greater than at any time during the last $150-200$ years. Elk are abundant in Fennoscandia, where the population was estimated at about $500000-700000$ by Nygrén (1986).

Surveys of helminths in elk have not been made in northern Alaska, where the wolf is the natural final host of E. granulosus. The Nunamiut hunted elk within the northern limits of the taiga only rarely, or when reindeer were not available. Farther inland, moose no doubt served as a source of infection of sled-dogs. In one relatively small agricultural area in south-central Alaska, where dogs were the major, if not only, final host, $24 \%$ of 101 elk were infected (Rausch, 1959). In the taiga farther to the south in Canada, the cycle of the cestode becomes complex due to the presence of another wild canid, the coyote
(Camis latrans L.), and additional species of deer. Records of the metacestode in elk in the Soviet Union were summarized by Nazarova (1967), who listed data for series of animals sampled in 9 regions, from the Leningradsk Oblast', in the west, to Iakutia, in XE Siberia. Of $188 \mathrm{elk} /$ moose included in the survey, $28(15 \%)$ were infected, with an intensity of only one to 9 cysts. Nazarova stated that the metacestodes usually occurred in the lungs and liver, but that other organs also were involved. Kheriuvimov (1967) reported findings in 50 elk examined during the hunting seasons of 1962-1964 in the Tambovsk Oblast'. He stated that the mean prevalence was $8 \%$, and that all of the cysts were in the liver. Kadenatsii \& Zinov'ev (1973) found infected elk/moose in all regions for which they obtained information (western Siberia and the Khabarovsk Krai). In montane tundra in eastern Siberia, $22(71 \%)$ of 31 elk were infected (Kikot', 1980). Isakov \& Safronov (1990) stated that available data indicated that more than 77000 elk inhabited Iakutia, occurring not only in the taiga, but not uncommonly in regions of tundra, where they reached the shores of the Arctic Ocean. In Iakutia, 3000-3500 elk were killed annually by hunters, during the period 15 July to 1 January. Isakov \& Safronov stated that each hunter had 2-3 dogs or more; that the dogs received the lungs and liver of elk killed; and that those so infected were the source of echinococcosis in the human population. Of 17 dogs examined in one village, $3(18 \%)$ were infected. Of 12 elk from one region, 7 (58\%) were infected; of 30 from various regions, the metacestode was present in $25(83 \%)$. Of $42 \mathrm{elk} / \mathrm{moose}$ in all, $32(76 \%)$ were infected; cysts, numbering from one to 41 per animal, were present in the lungs of all, and in the liver of 2 . Wolves also were a source of infection for elk; of 52 of those canids examined, 29 (56\%) harboured the cestodes. From those data, a conclusion is that natural cycles as well as semisynanthropic cycles contribute to the acquisition of echinococcosis by the villagers in Iakutia.

In North America, comprehensive, long-term investigations of the interaction of wolves and elk/ moose, and factors influencing the transmission of E. gramulosus in natural populations, have been conducted on Isle Royale, which is situated in Lake Superior, at the southern limit of the taiga. That island ( $72 \mathrm{~km}$ in length and $14 \mathrm{~km}$ in maximal width) is unique with respect to the mammalian fauna in that only one species of canid, the wolf, and one species of cervid, the elk (Alces alces), occur therc.

'The population of wolves on Isle Royale varied over the years from one to 2 packs, with totals ranging from 15-31. From 1960-1976, numbers of elk ranged from 700 in 1960 to a maximum of 1100 in 1969 (Peterson, 1977; Allen, 1979). The biology of wolves differed little from that at higher latitudes. After leaving the dens, the young animals occupied rendezvous-sites, which were changed at intervals 
of 6-30 days. The young abandoned those sites in autumn or early winter and joined the adults in hunting.

During the warm months, the prey of the wolves consisted mainly of elk-calves and beavers, Castor canadensis Kuhl, which in combination made up about $90 \%$ of the diet (Peterson, 1977). As a consequence, infection of wolves by the cestode would be unlikely during spring and summer. The metacestodes evidently become infective when young elk are about 2 years old. In a pen-reared calf (Alces alces), necropsied 8 months after receiving eggs of E. granulosus from a dog (that had been given a cyst from a naturally infected reindeer 70 days earlier), pulmonary cysts were from $2-2.5 \mathrm{~mm}$ in diameter (mean ca. $2 \cdot 2 \mathrm{~mm}$ ). In a wild moose about 16 months of age, a single pulmonary cyst contained a few brood capsules (R. I. Rausch, unpublished). Sweatman \& Williams (1963), in dogs experimentally infected with metacestodes from elk, determined the prepatent period to be 56-65 days, with maximal expulsion of eggs occurring as early as 76 days postinfection. In 2 dogs that had each received a single cyst $4-4.5 \mathrm{~cm}$ in diameter, from a naturally infected moose, $55000-60000$ cestodes were present at necropsy (Rausch, 1993). Since the life-span of the strobilar stage of the cestode ranges from about 8 months to a year (Sweatman \& Williams, 1963; Rausch, 1993), it is evident that wolves that became infected during the cold months when they prey mainly on adult elk would expel eggs during the following spring and summer.

From late autumn until spring, packs of wolves on Isle Royal hunted elk/moose more or less continuously within the limits of their respective territories. During the period 1959-1961, a pack of 16-17 killed one moose every $3-3 \cdot 7$ days. Adult moose were typically attacked at the hindquarters (Peterson, 1977 ; Buskirk \& Gipson, 1978). When a moose was killed, the wolves first fed on the rump, initially injured, and then opened the abdomen whereupon the heart, lungs and liver were consumed (Allen, 1979). Thus, one can conclude that in winter, the lungs were eaten promptly before the viscera could freeze; thereby, protoscoleces were infective when ingested. Adult moose that stood their ground when attacked by wolves usually escaped; consequently the rate of hunting-success by the wolves was rather low.

Peterson (1977) and others observed that predation was most severe on older animals, with the rate of kills increasing steadily after elk attained an age of 7 years. Peterson stated (p. 145) that 'After 8 years, the percentage occurrence in the kill is greater than the calculated percent occurrence in the population.' As a consequence, the preponderance of moose consumed by wolves would consist of those most massively infected. In a series of moose 7 years of age or older, numbers of metacestodes per animal ranged from $2-80$, with a mean of 38
(Peterson, 1977, Table 34). The cysts, mostly in the lungs, attained a diameter of about $25 \mathrm{~mm}$. All observations indicate that moose continue throughout life to accumulate metacestodes of E. gramulosus. Addison, Fyvie \& Johnson (1979) found that 36 $(67 \%)$ of 54 moose examined in Ontario, Canada, had metacestodes in the lungs, but also in the liver $(33 \%)$, spleen $(17 \%)$, and heart or kidneys $(2.8 \%)$. They reported that animals of the oldest age-group of their series included individuals that had 125,131 and 167 cysts, respectively.

When pulmonary infections in moose are massive, crowding or other factors may induce degenerative changes in the metacestodes. An old female moose, in poor physical condition and having numerous viral papillomata about the head, was killed for necropsy in south-central Alaska (R. L. Rausch, unpublished). More than 110 metacestodes were present in the lungs. A radiogram of the right lung was made, after which each cyst was dissected free and its location marked on a film in order to correlate condition with radiographic appearance. The 51 cysts examined, the largest being $7.5 \mathrm{~cm}$ in greater diameter, exhibited a range of conditions (Fig. 3). 'Thirtytwo were normal, and contained protoscoleces; 8 contained convoluted, degenerating membranes with calcification; daughter cysts were present in $3 ; 2$ were normal with calcified areas in the pericyst; 1 had collapsed membranes; and in 4 the membranes were necrotic, with only cascous debris remaining (some, at the periphery of the plate, were not characterized). Although many cysts conceivably were showing the effects of age and/or crowding, a large number of well-formed, apparently infective protoscoleces was present. That moose would have been highly vulnerable to predation, but wolves were not present in the arca, and domestic dogs rarely, if ever, attack adult moose.

\section{The sunanthropic cycle}

The synanthropic cycle of the northern biotype mainly involves domesticated reindeer and domestic dogs. Domesticated deer, however, may also become infected when they use range in areas where wolves are present. By the 1960 s, the reindeer industry in the Soviet Union was of great extent, with the major concentrations of herds in the western Arctic and in northeastern Siberia (Zhigunov, 1968). According to Zhigunov, the stock of reindeer in that country as of 1 January 1961, was 2092000 head. At the time, more than 500 veterinary institutions, employing ca. 2000 veterinary surgeons and technicians, had been established 'for veterinary and zootechnical services for the reindeer.' Socio-economic changes during recent years in Russia have had an adverse effect on the reindeer industry and have contributed also to increasing prevalence of cystic echinococcosis in the 


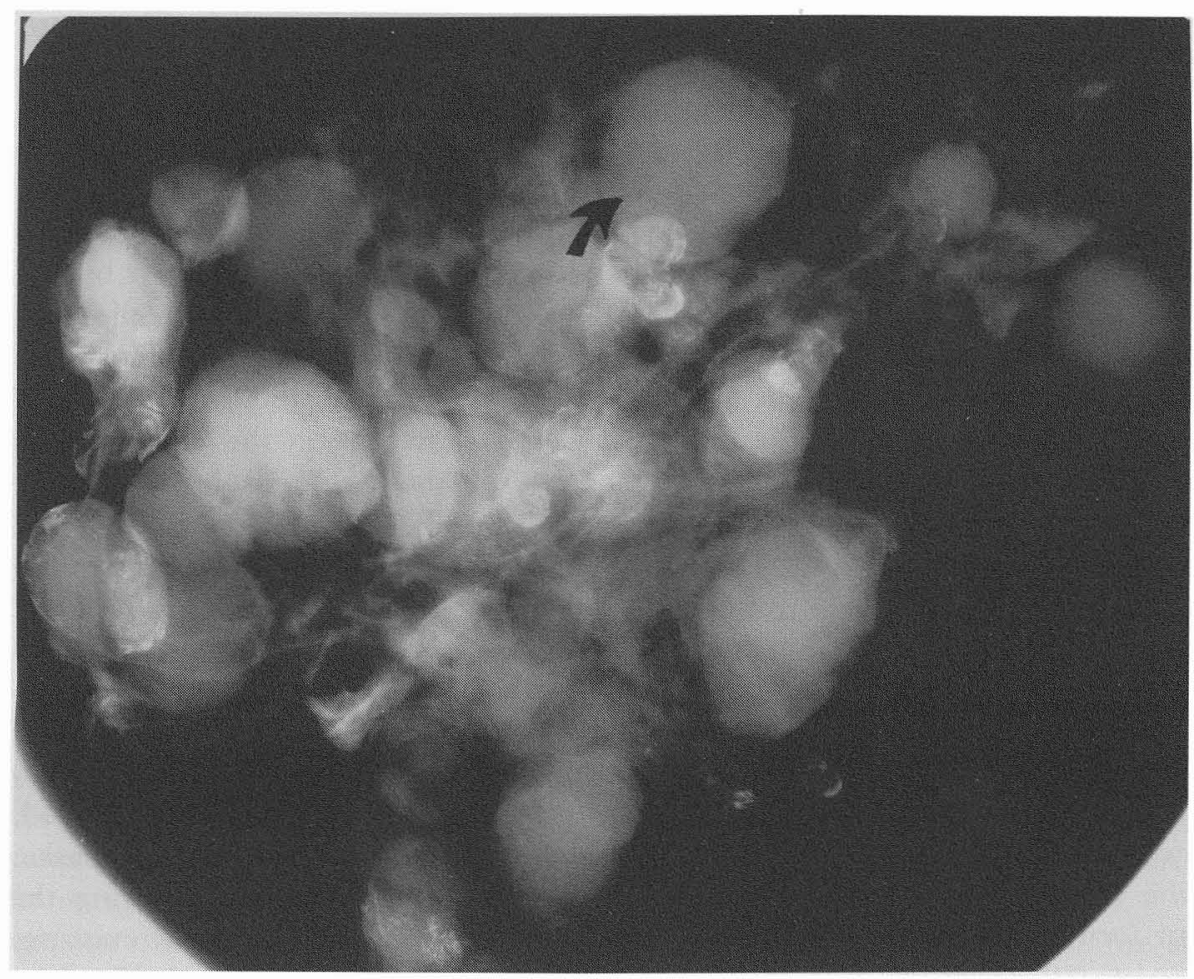

Fig. 3. Radiograph: Metacestodes of E. gramulosus in the lung of a naturally infected elk (moose). The largest cyst (arrow at top middle) measured $7.5 \mathrm{~cm}$ in greater diameter.

human population (Romanenko, Chernyshenko \& Sabgaida, 2001).

The most comprehensive early data available concerning the prevalence of the metacestode in domesticated deer in northeastern Siberia appear to be those of Ovsiukova (1966), who began surveys on various collective farms in 1953. She stated that over several years on separate farms, the maximal prevalence observed was $70 \%$. On one farm where 7427 deer were slaughtered over a period of years, Ovsiukova recorded prevalences as follows: 1954, $70 \% ; 1956,58 \cdot 7 \% ; 1958,18 \cdot 1 \% ; 1959,41 \% ; 1962$, $48 \%$; and $1963,25 \cdot 1 \%$. The mean prevalence was $45.8 \%$. Ovsiukova observed also that findings on farms in tundra and forest-tundra differed. On 6 farms in the zone of tundra, $3803(34 \cdot 1 \%)$ of 11157 deer were infected; on 5 farms in forest-tundra, 507 $(8.9 \%)$ of 5721 were infected. In 200 deer up to a year in age, no metacestodes were found; at an age of one to 2 years, $20 \cdot 5 \%$ were infected. Up to 34 metacestodes occurred in the lungs of individual animals (suggesting a cumulative effect not recorded in wild reindeer, but typical in elk). Of 586 dogs necropsied by Ovsiukova, $33(5.6 \%)$ harboured the cestodes, which ranged in numbers from 59-52582 (mean $18319)$ per animal. The highest rates were recorded in herding dogs, with the cestode in $22(35 \%)$ of 63 ; rates were much lower in sled-dogs, of which $11(2 \cdot 1 \%)$ of 523 animals were infected. Highest rates in sled-dogs were recorded in villages, usually inhabited by indigenous persons. In the zone of tundra (villages of Lavrentiia and Uelen), the prevalence in dogs was $14.9 \%$; in a village in foresttundra (Markova), the rate was $11.5 \%$. Dogs working with herds were the most often infected (up to $67 \%$ ). Ovsiukova (1975) also discussed the role of wolves in relation to the reindeer industry in the Chukotsk National Okrug, in northeastern Siberia. Not only did the wolves prey on the deer but, by contaminating the range with faeces, they contributed an additional source of infective eggs. In northwestern Siberia, in the Iamalo-Nenets National Okrug, $15-30 \%$ of the deer were infected. There also, Azeeva (1989) recorded the cestode in ca. $6 \%$ of 52 dogs.

In northeastern Siberia, echinococcosis has been a common disease among reindeer-herders and others, depending on their occupation. As noted by Ovsiukova (1966), 5 to 12 herding dogs were associated with each herd; of those, every third animal was infected by E. granulosus. A survey made by means of the Casoni test in villages in the Anadyr'sk and Providensk regions in 1964 gave positive reactions in up to $40 \%$ of reindeer herders, and $53 \%$ of dog-breeders. More recently, Nemurovskaia et al. (1980) stated that in the Chukotsk, Providensk, Anadyr'sk and Beringovsk regions of the Chukotsk National Okrug, the rate of echinococcosis per 1000 persons was $19 \cdot 7$ in 1976, and 22 in 1977. Among reindeer-herders, hunters and some others, rates ranged from $50-70$ per thousand. According to Romanenko et al. (2001), the prevalence of echinococcosis had increased significantly during the last decade. Greater numbers of new cases had been 
diagnosed yearly in Russia, from 130 in 1991 to 480 in 1999. As before, the problem was especially severe among the indigenous peoples in Siberia (Sakha Republic [= Iakutia], Koryak Autonomous District and Chukchi Autonomous District), where reindeer herding and subsistence hunting presumably are of increasing importance. Romanenko et al. stated that increasing numbers of children were infected, with a rise in morbidity from 0.02 in 1991 to 0.3 in 1999. The worsening of the epidemiological situation was attributed in part to reduced medical and veterinary services and, evidently, to worsening economic conditions, as a consequence of deterioration of the social situation in the northern regions of Russia.

In western Eurasia (Fennoscandia), echinococcosis formerly occurred mainly among the Saami, who used dogs in reindeer-herding. In Finnmark, in northern Norway, Skenneberg (1959) reported a rate of infection of $9.6 \%$ in 2204 reindeer. In northern Sweden, Söderhjelm (1969) noted that the prevalence of the metacestode in the lungs of reindeer differed from herd to herd, but formerly had been about $10 \%$. Also in Sweden, Ronéus (1974) reported that pulmonary infections were found in only 23 of 1453 animals, with ranges varying from less than 1 to $2 \cdot 1 \%$. In Finland, Hirvelä-Koski et al. (2003) reported that the metacestode had been found in only one domesticated reindeer during the period 1979-1991, but that cases had been diagnosed annually since 1992, with a total of 59 by the year 2001. 'The rate for all slaughtered deer ranged from $0 \cdot 008-0 \cdot 121$ per thousand; for adults (over one year of age), the rate was $0 \cdot 23-0.453$ per thousand. Hirvelä-Koski et al. concluded that the cestode does not now occur in dogs in northern Finland, and noted that since the 1960 s machines have replaced dogs in herding. 'They determined that $E$. gramulosus occurs in about $30 \%$ of wolves in eastern Finland, where wild reindeer serve as intermediate host, but those canids are not permanent residents in the reindeer-herding districts.

Huldt et al. (1973) reported the results of application of various diagnostic tests for echinococcosis in 586 Saami in Kautokeino (arctic Norway). As is typical of infections involving the northern biotype, lack of immunogenesis rendered immunodiagnostic tests to be more or less useless when compared with the results obtained from immigrant persons infected by other strains of the cestode. Huldt et al. noted that the weak or absent immune response could be attributable either to some genetic characteristic of the Saami or to the lack of immunogenesis evoked by the cestode.

Domesticated reindeer were introduced into Alaska from northeastern Siberia and arctic Norway during the last years of the 19 th century (Rausch \& Baldwin, 2002). Subsequently, natural increase led to the establishment of numerous herds, mainly in the northern and western regions of the Territory. According to Hadwen \& Palmer (1922), about 100 herds existed there by the early 1920s. Lantis (1950) stated that the number of animals totaled about 57872 by 1914 , after which a decrease to about 27920 had taken place by the summer of 1931 . The herds on the arctic slope disappeared by the early $1950 \mathrm{~s}$, most of the animals joining the wild reindeer as their supervision was neglected. At the present time, an estimated 7000-10000 of the domesticated deer are present on the Seward Peninsula, northwestern Alaska (M. Robus, personal communication).

Hadwen (autobiography, 1938, p. 131) reported the presence of pulmonary cysts in deer at the experimental station at Unalakleet (NW Alaska) established in 1920 at the site of the original reindeerstation (Rausch \& Baldwin, 2002). Hadwen \& Palmer (1922) stated that E. granulosus had been reported, in a footnote to an unpublished report dated 1914, in dogs associated with domesticated herds in Alaska. No recent information is available concerning the occurrence of helminths in the herds now existing. In Alaska, machines have replaced dogs for herding (M. Robus, personal communication).

A recommendation to establish domesticated reindeer in Canada was made in a report by a royal commission (Rutherford, McLean \& Harkin, 1922), and animals were imported from northeastern Siberia during 1933-1935 (Banfield, 1961). 'The first report of $E$. gramulosus in those deer was evidently that of Choquette et al. (1957), who examined numerous animals at the Canadian Reindeer Depot, situated near Aklavik, at the mouth of the Mackenzie River, Northwest Territories. They recorded prevalences: in 1953, $28(6.7 \%)$ of 462 deer; 1954,41 $(6.5 \%)$ of 627 ; and $1955,89(15.5 \%)$ of 575 . At that time, lungs of slaughtered deer were discarded where they were available to unrestrained dogs. Choquette et al. recognized that the deer could also become infected when they were herded on range inhabited by wolves. In Canada at the present time, a single herd of $3000-4000$ animals is maintained on Richards Island, in the eastern section of the Mackenzie Delta. No dogs are involved in herding, which is now done with use of snow-machines in winter and all-terrain vehicles in summer (G. Spearman, personal communication). A disadvantage of modern methods of reindeer-herding is that the vegetation on tundra underlain by permafrost is severely damaged by the passage of motorized vehicles.

\section{The semi-synanthropic cycle}

At least until the late 1960s, many Iñupiat and other indigenous peoples in northern North America depended on the hunting of wild reindeer and moose/ elk for subsistence. Those animals also provided 
food for sled-dogs, which were essential for travel in the Arctic and Subarctic. When firearms replaced aboriginal weapons, hunting of large animals was facilitated and, by the early $1950 \mathrm{~s}$, supposed competition with the dominant culture in utilizing reindeer and moose became a political issue (Rausch, 1953). Aside from alleged instances of waste of game by indigenous hunters, the feeding of wild reindeer to the dogs was especially criticized in Alaska. In Canada, major concern was that excessive numbers of reindeer were being killed during a period of years when numbers of the animals were believed to be significantly declining (Kelsall, 1968, for review). One consequence of the controversy was the initiation of programmes of 'predator control' in both countries, with the objective of reducing the killing of deer by wolves. The numbers of wolves eliminated wcre large, but modest as compared with the very many killed to protect domesticated reindeer in the Soviet Union (Kozlov, 1966). Whether predator control in North America and Russia affected the transmission of taeniids is not known, but transmission of some infectious diseases of wild reindeer probably was enhanced.

Echinococcosis among hunters and herders in the Arctic and Subarctic was a consequence of the people's association with domestic dogs. In settlements where wild deer were an essential resource, dogs were commonly infected by E. gramulosus. On the arctic coast, $7(10 \%)$ of 69 were infected, as were $8(22 \%)$ of 37 from inland villages (R. L. Rausch, unpublished). The first case of echinococcosis diagnosed in Alaska was reported in a newspaper, the Nome Gold Digger, on 14 Febuary 1900, in a miner from Kotzebue. The next record was that of Williams (1948). Rausch (1960) listed a total of 41 cases, all in indigenous persons. Wilson et al. (1968) reviewed 101 cases in indigenous people in Alaska. Castrodale et al. (2002) reported that more than 300 cases of echinococcosis had been diagnosed in Alaska through the year 1990, but that only 3 cases had been recorded during the period 1991-1999.

In most settlements, one could assume that, on average, the number of dogs present was about twice that of the human population. Not until dogs were replaced by machines did the indigenous peoples become essentially free of echinococcosis. An example of the sequence of events leading to the elimination of echinococcosis in one population is described here, based on my obscrvations over the period April 1949-August 1969.

In 1949, one group of nomadic Iñupiat remained in the central Brooks Range, in arctic Alaska (Rausch, 1951; Spearman, 1979). Although they also hunted wild sheep and brown bears to some extent, they depended on wild reindeer for subsistence, as well as for skins for clothing, housing, and other needs. Each family had a number of large, powerful dogs, 9-10 of which were needed to draw a loaded sled in the mountainous terrain. In the summer of 1949, the group numbered 71 persons, in 12 families. The people camped at a single site during the warm months, when travel by dog-sled was not practicable, but hunters often made long trips on foot, accompanied by pack-dogs. With the onset of cold weather, in October, the families dispersed to their customary areas for trapping and hunting. Dwellings of reindeer-skins, easily transported by sled, were mostly used in winter. During the warm months, the dogs were chained at some distance from the dwellings, but the faecal production by about 200 animals was significant. 'The dogs were highly valued; 6 only could be obtained for necropsy during the period April 1949-October 1950, of which one was infected by E. gramulosus. Where wild deer were killed on the tundra, the viscera were left in the field and were not given to sled-dogs. Young dogs, however, frequently were allowed to accompany hunting expeditions, and unrestrained, they often were able to consume viscera of deer (Fig. 4).

The nomadic life-style began to change in 1951, when a post-office was established in montane tundra, at the summit between the headwaters of the arctic and Yukon drainages, about $64 \mathrm{~km}$ north of the timberline (taiga). 'That, along with later construction of a school by the Territory of Alaska, led to the gradual formation of a permanent settlement. Dogs were still much used, and 216 of the animals were present in April 1962.

Under the conditions that developed, the village became increasingly soiled by the faeces of dogs, much to the dismay of the people. As a consequence of such contamination, echinococcosis appeared in the population. During the period January 1957 to October 1968, 5 cases were recorded, in 3 males and 2 fcmales, who ranged in age from 7 to 39 years (mean 22 years). In the 1960 s, mechanized vehicles (snow-machines) became generally available. In the winter of 1968-1969, only one hunter used dogs; another had done so until December 1968, when he too purchased a machine. As of August 1969, the village had 14 machines, and only 108 dogs remaincd. Some hunting and trapping were done, but replacement of dogs continued. Less effort was made in trapping, and the area in which hunting was undertaken was reduced, so that round trips usually took no longer than 2 days. By 1979, the village had a population of 180 . Each family had one or two machines, including snow-machines as well as all-terrain vehicles that were used during the warm months. Only one dog-team was present, but most families kept $2-3$ dogs as pets. That practice has continued. Records of vaccinations of dogs against rabies, maintained at the Veterinary Clinic of the North Slope Borough, at Barrow, showed the numbers of dogs present in the village in recent years to be: 55 in 2000 ; 91 in 2001; and 78 in 2002 


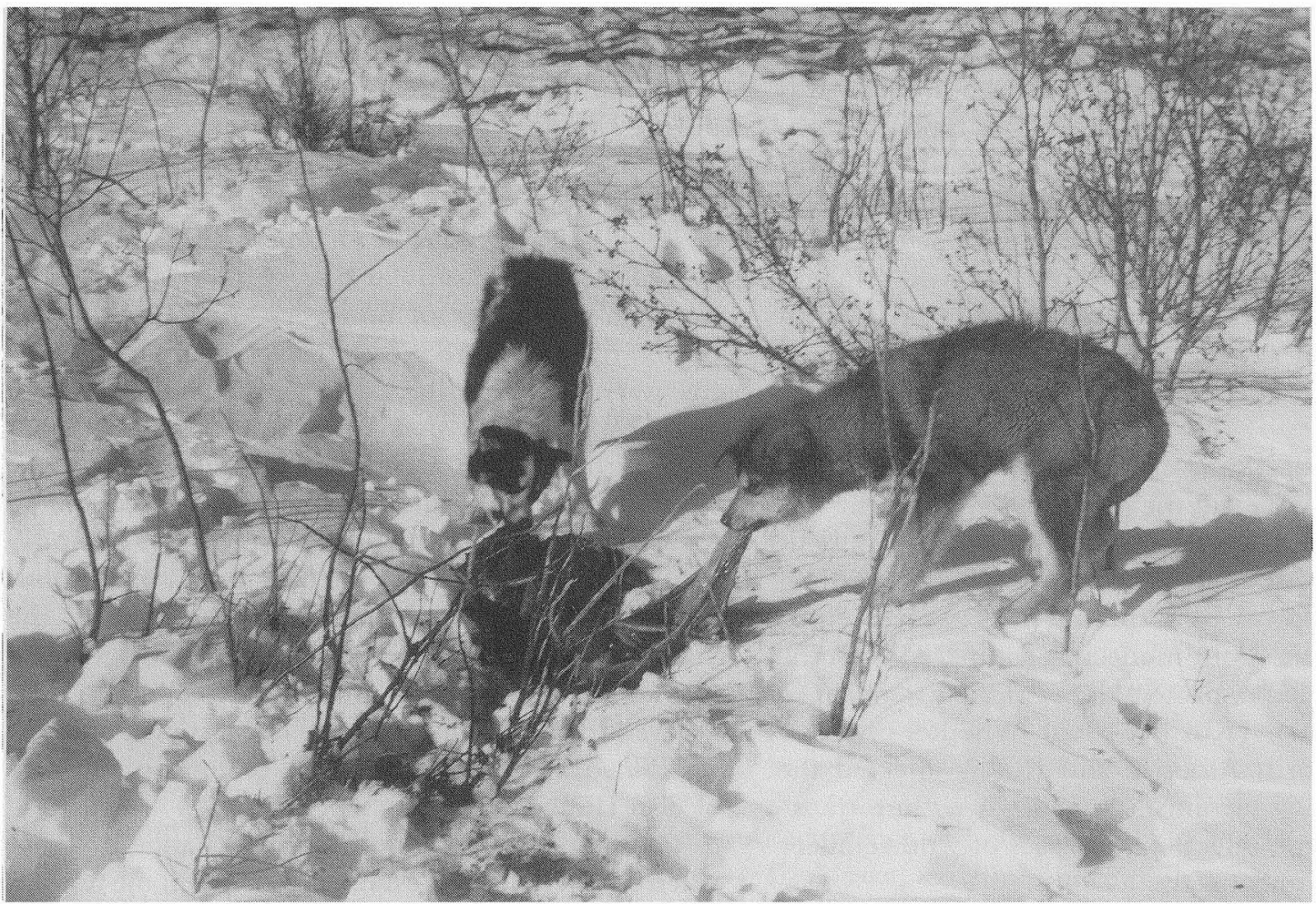

Fig. 4. Young dogs consuming the discarded viscera of a wild reindeer.

(C. Hanns, personal communication). There is no indication that echinococcosis occurs there at present; the village, now with modern facilities, has a population of approximately 300 people.

The replacement of dogs by machines not only in Alaska but also in Canada and in Fennoscandia appears essentially to have eliminated cystic echinococcosis in the human populations; the prevalence of the metacestode in domesticated reindeer seems also to have been much reduced. Occurrence of the metacestode in deer, however, can be expected when the herds coexist with wolves. Increasing prevalence of echinococcosis in northern Russia suggests that herd-dogs continue to be used there.

I) Iscusiston

Eight strains of Echinococcus gramulosus have been distinguished by mitochondrial sequences (Bowles, Blair \& McManus, 1995). Several occur sympatrically in different regions of the world, perhaps indicating repeated introductions via domestic animals especially since the early 16th century (Rausch, 1967). Of those eight strains, that occurring in natural hosts in the Arctic and Subarctic is characterized by biological and phenotypic uniformity. Sympatric with the northern biotype (E. gramulosus) is the cestode historically designated Echinococcus multilocularis, the hosts of which are foxes and rodents. The molecular-genetic analyses of Bowles et al. (1995) and others have led to a conclusion that E. multilocularis is also a strain of E. gramulosus and the two therefore would be conspecific. The two taxa, however, differ biologically and morphologically to an extent indicative of their status as distinct species that evolved independently. The geographic range of E. multilocularis in the Palaearctic indicates that it is of Eurasian origin, and that it spread into North America during post-glacial time, perhaps from Beringia where its hosts were present at least by Würm time (Kurtén \& Anderson, 1980).

Taxonomic conclusions based on classical morphological characters for taeniids (cf. Hoberg, Jones et al. 2000) and on conclusions based on moleculargenetic data are not congruent. Further investigation is needed to resolve the problem.

The distributional histories of the hosts of Echinococcus spp. provide some indications about the age and specific independence of the four recognized species. The hosts of the northern biotype (the wolf and the reindeer) have had an holarctic distribution since at least late Irvingtonian Age, more than a million years ago (Kurtén \& Anderson, 1980). That a species of the genus Echinococcus occurred in North America by early Pleistocene time is indicated by the origins of the two neotropical species of that genus. Carnivores of the families Canidae and Felidae appeared in the fossil record in South America in deposits of early Uquian Age (early Pleistocene) (Simpson, 1980). Mammals of both families underwent considerable radiation on that continent. Hershkovitz (1969) considered that each of the extant genera of Canidae arose independently from ancient Middle American stock, rather than from 
a common ancestor. The precursor(s) of the 2 neotropical species of Echinococcus must have dispersed into South America by early Pleistocene time; the cestode-host assemblages that arose evidently involved coevolution with hystricognath rodents, which are their typical intermediate hosts. Those rodents were first recorded in the Oligocene of South America, reappearing there in the early Miocene following an hiatus in the fossil record (Simpson, 1980). Several species of the genus Taenia now occurring in felids spread with their hosts into South America during the late Pleistocene, while other tacniids, including $E$. gramulosus, were introduced recently (Lühe, 1910; Rausch, 1967). Evidently, species of cestodes have arisen earlier than have species of mammalian hosts in which they occur (Hoberg, Alkire et al. 2000). Numerous examples of temporal relationships are discernible (cf. Rausch, $1980)$.

Within the constraints of the international rules of zoological nomenclature, all criteria of possible taxonomic significance must be considered: morphology, biology, distributional histories of hosts and genetics.

\section{REFERENCES}

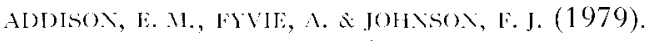

Metacestodes of moose, Alces alces, of the Chapleau Crown Game Preserve, Ontario. Canadian foumal of Zoology 57, 1619-1623.

ALLIN, 1). I. (1979). Wolves of Minong. Their Vilal Role in a Wild Community. Boston, Ioughton Mifflin Company.

ASADON, s. M. (1960). Gel'mintofauna shvachnykh

shivotnykh SSSR i ee ekologo-geograficheskii analis.

Akademiia Nauk Azerbaidzhanskoi SSR.

AzEL A, N. (i. (1989). Ekhinokokkoz v Nenetskom

Avtonomnom Okruge. Meditsinskaia Parazitologïa $i$ parazitarnye bole $\approx n i$ 5, 65-68.

baxfinad, A. W. F. (1961). A Revision of the Reinder and

Caribou, Gemus Rangifer. National Museum of Canada, Bulletin No. 177. Ottawa, Roger Duhamel.

Bowles, 1., BIAIR, D. A NAMANL', D. P. (1995). A molecular phylogeny of the genus Echinococcus. Parasitology 110 , $317-328$

BCSKIRL, S. W. \& GIPSON, P.S. (1978). Characteristics of wolf attacks on moose in Mount Mckinley National Park, Alaska. Artic 31, 499-502.

CAveron, 'T. W. M. (1960). The incidence and diagnosis of hydatid cyst in Canada. Echinococcus gramulosus var. canadensis. Parassitologia 2, 381-390.

CASTRODALE, 1.. J., BELLLIR, .I., WILSON, J. I., SCHANT\%, P. M., MIANCS, D. F., ZIIAXC, I,-H., FALLICO, F. G. \& SACCO, F. D. (2002). 'l'wo atypical cases of cystic echinococcosis (Echinococcus granulosus) in Alaska, 1999. American Fournal of Tropical Medicine and Hygiene 66, 325-327.

CIOQLET"TE, L. P. R., GIPSON, G. G., KUYT, E. \& PEARSON, A. M. (1973). Helminths of wolves, Canis lupus L., in the Yukon and North West Territories. Canadian Fournal of Zoology 51, 1087-1091.

CHOQLLTTE, I. P. L., WHITIEN, L. K., RANTIN, G. \& SEAL, C. M. (1957). Note on parasites found in reindeer (Rangifer tarandus) in Canada. Canadian Youmal of Comparatize Medicine 21, 199-203.

GEY'TNER, V. G., NASIMOVICII, A. A. \& BAYNIKOV, A. (i. (1961). Mekopitainshchie Sovetskogo Soiuza. Artiodactyla $i$ Perissodactyla. Vol. 1. Moskva, Vysshaia Shkola. (ILPTNER, V. (.., NALMOV, N. P., ILRGLNSON, P. B., SLLIDSKH, A. A., CHRKOVA, A. F. \& BA.VNIKOT, A. (. (1967).

Mekopitaiuschie Sozetskogo Soiuza. Morskie Korozy $i$

Khishchye. Vol. 2. Moskva, Vysshaia Shkola. llabwex, s. (1938). Autobiography. Ottawa, The Permanent Mission of Canada to the United Nations. HADWLN, S. \& PMAMLR, L. J. (1922). Reindeer in Alaska.

Washington, DC., US. Government Printing Office. marpir, 'T. A., RUtTan, R. \& Blison, W. A. (1955). Hydatid discase (Echinococcus gramulosus) in Saskatchewan big game. Transactions of the North American Wildife Conference 20, 198-208.

IftrRe, W. (1955). Das Ren als Haustier. Akademische Verlagsgesellschaft. Lcipzig, Geest \& Portig. ILERstIKOVIY\%, P. (1969). 'The evolution of mammals on southern continents. The recent mammals of the neotropical region: a geographic and ecological review. Part 7. The Quarterly Requer of Biology 44 , $311-431$.

HIRVLLÄ-KOSKI, V, HALKISALAII, V., RIIPELÄ, S.-S., NYLCND, M. \& Koski, P. (2003). Echinococcus granulosus in Finland. Veterinary Parasitology 111, 175-192.

HOBERG, E. P'., ALKIRE, Y. L., DL QLEIROZ, A. \& JONTS, A. (2000). Out of Africa: origins of the Taenia tapeworms in humans. Proceedings of the Royal Society of London 268, 781-787.

HOBIRG, E. P., JONES, A., RMTSCH, R. L., EOM, K. S. \& (GARDER, S.L. (2000). A phylogenetic hypothesis for species of the genus Taemia (Eucestoda: 'l'aeniidae). Foumal of Parasitology 86, 89-98.

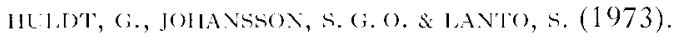
Echinococosis in northern Scandinavia. Archizes of Encirommental Health 26, 36-40.

ISAKOV, S. I. \& SAlRONOV, M. (i. (1990). Los' promezhutochnyi khoziain Echinococcus gramulosus v Iakutii. Meditsinskaia Parazitologiia i parasitarnye bolezni 2, 58 .

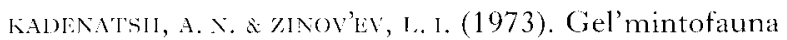
losia v svete izucheniia prirodnoi ochagovosti gel'mintozov. Voprosy Prirodnoi Ochagorosti bolezmi 6, 139-143.

KELSALl, J. P. (1968). The migratory Barren-ground Caribou of Canada. Ottawa, 'The Qucen's Printer.

KHERIUVINOU, Y. D. (1967). O nekotorykh parazitakh i bolezniakh losei Tambovskoi Oblasti. In Biologïa i promysel losia (cd. Bannikov, A. G.). Moskva, Rossel'khozizdat.

KIKO'T', v. 1. (1980). Prirodnaia ochagovost' ekhinokokkoza v gornotaezhnoi zone dal'nego vostoka. Meditsinskaia Parazitologiia i parazitarnye boleani 49, 60-63.

KOZLov, r. (1966). Volki lesostepei Sibiri i ikh istreblenie. Krasnoiarsk, Krasnoiarskoe Knizhnoe. Fut'Tin, B. \& Avidirson, F. (1980). Pleistocene Mammals of North America. New York, Colombia University Press. LANTIS, .1. (1950). 'The reindeer industry in Alaska.

Arctic 3, 27-44.

Lï11E, M. (1910). Cystotänien südamerikanischer Fcliden. Zoologische Fahrbücher 12 Suppl., 687-710. 
LLKASHENKO, … (1975). Al'veokokkoz (al'veoliamyi ekhinokokkoz). Moskva, Meditsina.

MWMANUS, D. P., ZHANG, L., CASTRODALE, I. J., LE, T. II., PEARSON, M. \& BLAIR, D. (2002). Molecular genetic characterization of an unusually severe case of hydatid disease in Alaska caused by the cervid strain of Echinococcus gramulosus. American Fournal of Tropical Medicine and Hvgiene 67, 296-298.

MECII, I. D. (1970). The Wolf: The Ecology and Behavior of an Endangered Species. New York, The American Museum of Natural History, 'The Natural History Press, Garden City.

NFL'T\%ER, H., KOVACS, L., ORFORT), 'T. \& NA'lAS, M. (1956). Echinococcosis in North American Indians and Eskimos. Canadian Medical Association Fournal 75, 121-128.

MISSELICH, V. IU. \& SAVEL'EV, V.D. (1975). O roli dikogo severnogo olenia v epizootologii invazionnykh 'zabolevanii na Taimyre. In Dikii severnyi olen' $v$ SSSR (cd. Syroechkovskii, E. E.), pp. 117-120. Sovete Ministrov RSISR, Moskva, Sovetskaia Rossiia. Mirif, A. (1944). The Wolves of Mount McKinley. Fauna of the National Parks of the United States, Fauna Series No. 5. Washington, DC., US. Government Printing Office.

SAzAROMA, s. (1967). Gel'mintofauna losia v Sovetskom Soiuze. In Biologia i promysel losia (ed. Bannikov, A. G.), pp. 288-312. Moskva, Rossel'khoziadat.

NENIIROVSKAIA, А. I., NEKIPELON, V. 1., IAKOVIEVA, 'T. A. \& LSINski, A. A. (1980). Problema ckhinokokkoza v RSISR. Meditsinskaia Parasitologiia i parasitamye bolesni 49, 17-21.

MGREX, k. (1986). Alces alces (Linncus, 1758)- Elch. In Handbuch der Säugetiere Europas. Band 2/II. Paarhufer-Ariodactyla (Suidae, Cervidae, Bovidae.) (ed. Niethammer, J. \& Krapp, F.), pp. 173-197. Wiesbaden, ALLA Verlag.

osilkora, ‥ (1966). Gel'minty i osnovnye gel'mintozy mlekopitaiushchikh Chukotki. Dissertation. Vscsoiuznyi institut gel'mintologii imeni Akademika K. I. Skrjabina, Moskva.

ovstukova, … (1975). O roli volka v scvernom olenevodstve. In Dikï seoernyi olen' Syrocehkorskii, E. E.). pp. 134-138. Moskva, Sovetskaia Rossiia.

PAViox, M. P. (1990). Volk. Moskva, Agropromizdat. I'ETERsox, R. o. (1977). Wolf Ficology and Prey Relationships on Isle Royale. National Park Service Scientific Monograph Series, No. 11. Washington, DC., LS. Government Printing Office.

PETRON, A. M. \& DELLAxOVA, R. SH. (1962). Rasprostranenie vozbuditelei ckhinokokkoza i al'veokokkoza u domashnikh i dikikh plotoiadnykh v SSSR. Trudy Vsesoinsnogo Instituta Gel'mintologit imeni Akademika K. I. Skriabina 9, 67-87.

RALSCII, R.A. (1959). Notes on the prevalence of hydatid disease in Alaskan moose. Foumal of Wildife Management 23, 122-123.

RiUsch, R. L. (1951). Notes on the Nunamiut Eskimo and mammals of the Anaktuvuk Pass Region, Brooks Range, Alaska. Artic 4, 146-196.

RALSCIH, R. L. (1953). On the status of some arctic mammals. Arctic 6, 91-148.

RALSCH, R. L. (1960). Recent studies on hydatid disease in Alaska. Parassitologia 2, 391-398.
RALSCH, R. L. (1967). On the ecology and distribution of Echinococcus spp. (Cestoda: Taeniidae), and characteristics of their development in the intermediate host. Annales de Parasitologie humaine et comparée 42 , $19-63$.

RAUSCII, R. I. (1980). Redescription of Diandrya composita Darrah, 1930 (Cestoda: Anoplocephalidae) from nearctic marmots (Rodentia: Sciuridae) and the relationships of the genus Diandrya emend. Proceedings of the Ilelminthological Society of Washington 47 , $157-164$.

RAUscil, R. I.. (1993). The biology of Echinococcus gramulosus. In Compendium on cystic echinococcosis with special reference to the Xinjiang Uygur Autonomous Region, the Peoples' Republic of China (ed. Anderson, F. L., Chai, J.-J. \& I iu, F.-J.), pp. 27-56. Provo, Utah, Brigham Young University.

RALSCH, R. L. \& HUN'TLEY, B. E. (1978). Brucellosis in reindeer, Rangifer tarandus L., inoculated experimentally with Brucella suis, type 4. Canadian Fournal of Microbiology 24, 129-135.

RAlsch, R. L. \& WILIAMSON, I.s. I. (1959). Studies on the helminth fauna of Alaska. XXXIV. 'The parasites of wolves, Canis lupus I. Fournal of Parasitology 45 , $395-403$.

RAlsch, V.R. \& BALIDWIN, D. L. (2002). The Yukon Relief Expedition, with the Foumal of Carl Fohan Sakariassen. Fairbanks, University of Alaska Press.

REVIX, IU. V., SONIN, L. R. \& ZHEL:2.Nov, v. K. (1988). Snezhnyi baran. Morfologiia, syslematika, ekologiia, oktrana (ed. Solomonov, N. G.). Novosibirsk, Nauka.

ROMANEAKO, N.A., CIIERYSHENKO, A. I. \& SABGAIIA, T. P. (2001). Echinococcosis in Russia. In Abstracts. XXth International Congress of Hidatidology (ed. Altinas, N., Yolasigmaz, A., Coskun, E. \& Gunes, K.), p. 302. Turkey, Kusadasi.

ROCELS, O. (1974). Prevalence of echinococcosis in reindeer (Rangifer tarandus) in Sweden. Acta Velerinaria Scandinavica 15, 170-178.

RL'IIHERIOORD, J. (;., MLLLAN, J.S. \& HISRKIN, J. B. (1922). Report of the Royal Commission to Investigate the Possibilities of Reindeer and Musk-ox Industries in the Arctic and Sub-Arctic Regions of Canada. Ottawa, F. A. Agland.

SIMISON, G. (. . (1980). Splendid 1solation. The Curious Hislory of South American Mammals. New Haven and London, Yale University Press.

ShEN NEBER;, s. (1959). Ekinokokkose hos rein $\mathrm{i}$ Kautokeino. Nordisk Veterinaemedicin 11, 110-123. s.lT'I, P. V. (1957). Sundhedstilstanden i Gronland. I andslaegens arsberetning 1956. Beretninger vedrorende Gronland, Nr. 8. Godthăb, Sydgronlands Bogtrykkeri.

sömerinema, L. (1969). Hydatid disease, epidemic nephritis, and tularemia in northern Sweden. Archizes of Environmenlal Health 18, 127-132.

SPFARMAN, G. (1979). Land use values through time in the Anaktuvuk Pass area. Occasional Paper No. 22. Fairbanks, University of Alaska.

SWEA'MAX, G. K. \& WILLAAM, R. J. (1963). Comparative studics on the biology and morphology of Echinococcus granulosus from domestic livestock, moose, and reindeer. Parasitology 53, 339-390. 
SYRoECHKoYski, E. E. (1975). Problema dikogo severnogo olenia v SSSR na sovremennom etape. In Dikii severnyi olen' 2 SSSR (cd. Syroechkovskii, E. E.), pp. 14-50.

Moskva, Sovetskaia Rossia.

TAVROYSEII, V.A., EGOROV, O. V., KRIVOSHEEY, V. G., POPOV,

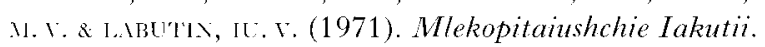
Moskva, Nauka.

THOMPSOX, R. C.A. \& WLANCS, D. P. (2002). 'Towards a taxonomic revision of the genus Echinococcus. Trends in Parasitology 18, 452-457.

HEBSTER, G. \& CAMER(X), 'T. W. M. (1961). Obscrvations on experimental infections with Echinococcus in rodents.

Canadian Foumal of Zoology 39, 877-892.
WILLIAMS, R. B. (1948). Echinococcosis or hydatid discase. Alaska's Health 6, 6.

WILSON, J. F., DIDDANS, A. C. \& RALsci1, R. L. (1968). Cystic hydatid disease in Alaska. A review of 101 autochthonous cases of Echinococcus granulosus infection. American Review of Respiratory Disecases $98,1-15$.

ZMBRODIN, V. A. \& LAISHEV, A. KH. (1980). Infektsionnye bolezni. In Bolezni severnykh olenei (ed. Zabrodin, V. A. \& Laishev, A. Kh.), pp. 5-77. Moskva, Kolos. ZHIGG Husbandry (ed. Zhigunov, P. S.), pp. 1-4. Jerusalem, Translation: Israel Program for Scientific Translations. 